\title{
Voltammetric estimation of the content of antibiotics in veterinary preparations
}

\author{
Galina Slepchenko ${ }^{1, *}$, Tatyana Gindullina ${ }^{1}$, Valentine Deryabina ${ }^{2}$, Tatyana Shchukina ${ }^{1}$, Aydin $\mathrm{Okanov}^{3}$ and Saule \\ Kabieva $^{3}$ \\ ${ }^{1}$ National Research Tomsk Polytechnic University, Tomsk, Russia \\ ${ }^{2}$ National Research University Belgorod State University, Belgorod, Russia \\ ${ }^{3}$ Karaganda State Technical University, Karaganda, Kazakhstan
}

\begin{abstract}
The voltammetric method for determination of tylosin tartrate, gentamicin sulfate, and cefalexin in veterinary preparations was for the first time developed. Electrochemical behavior of these antibiotics on the mercury film electrode was studied, and the working conditions (background electrolyte, deposition potential) were defined for getting analytical signals using the voltammetry. The methods of real objects preparation for determination of tylosin tartrate, gentamicin sulfate, and cefalexin were offered. The techniques for the voltammetric determination of antibiotics in the veterinary preparations may be used in cefalexin ranging from 0.1 to $2.0 \mathrm{~g} / \mathrm{dm}^{3}$, tylosin tartrate in the range from 0.1 to $1.7 \mathrm{~g} / \mathrm{dm}^{3}$, and gentamicin sulfate from 0.1 to $1.5 \mathrm{~g} / \mathrm{dm}^{3}$ ( $\mathrm{Sr}$ is not more than $25 \%$ )
\end{abstract}

\section{Introduction}

According to the monitoring Research Techart research company, about $19 \%$ of antibiotics are used - as growth promoters, $58 \%$ - as a prophylactic agents, $23 \%$ - for the treatment [1].

Gentamycini sulfas (GS), tylosinum tartrat (Tiltar) и cefalexinum (CF) - broad-spectrum antibiotics, which are used in the fields of agro-industrial complex of Russia. With a huge selection of products, practically solve the problem of counterfeit drugs, which is compounded by the fact that for a number of existing control methods of antibiotics is not completely meet modern requirements analysis. Therefore, the timely control of the content of antibacterial drugs - a problem that requires an immediate solution.

One of the first methods for quantifying antibiotic steel immunological and microbiological express - Tests [2, 3]. Among the physical and chemical methods of analysis of antibiotics popular planar chromatography (modern TLC), high performance liquid chromatography and capillary electrophoresis [4, 5].

Each of these methods has its advantages and disadvantages. These disadvantages are the duration of the analysis, the definition of a small range of concentrations, the low sensitivity of the method and the high cost analysis or equipment. Alternatively, these methods may make variations voltammetry (VA). VA taking into account the low cost of analysis and equipment, combine high information capabilities with ease of signal measurement process that allows, along with the definition of the content of the relevant substances in veterinary medicines to carry out pharmacokinetic studies.

\section{Experimental}

Chemicals and solvents

The aim of the work was to develop a way of measuring the voltammetric tylosin tartrate, gentamicin sulfate, cephalexin and methods of their determination in pharmaceuticals. Substances of antibiotics were provided by the "Altay - vitamins", Russia.

A stock solution containing $1000.0 \mathrm{mg} / \mathrm{dm}^{3}$ appropriate antibiotic was prepared by dissolving dry powder sample of pharmaceutical preparation (containing the basic substance is not less than $99.5 \%$ ) in bidistilled water. Working solutions - certified mixtures were prepared by serial dilution in double distilled water, basic solutions.

In order to select the operating examined supporting electrolyte of $0.1 \mathrm{~mol} / \mathrm{dm}^{3}$ solution: $\left(\mathrm{NH}_{4}\right)_{2} \mathrm{SO}_{4}, \mathrm{KCl}$, $\mathrm{Na}_{3} \mathrm{C}_{6} \mathrm{H}_{5} \mathrm{O}_{7}, \mathrm{C}_{6} \mathrm{H}_{8} \mathrm{O}_{7} \cdot 2 \mathrm{HN}_{3}, \mathrm{C}_{4} \mathrm{H}_{4} \mathrm{O}_{6} \mathrm{Na}, \mathrm{C}_{4} \mathrm{H}_{6} \mathrm{O}_{6}, \mathrm{C}_{6} \mathrm{H}_{8} \mathrm{O}_{7}$, buffer and Britton Robinson buffer citrate-phosphate mixture. Background electrolyte solutions prepared by dissolving the corresponding salts in the sample with bidistilled water. Instrumentation and voltammetric conditions 
The work on the voltammetric analyzer «STA» (LLC «ITM», Tomsk Russia). All studies were carried out on a mercury-film electrode (RPE) with the working surface $15 \mathrm{~mm}^{2}$. The auxiliary electrode and the reference electrode silver/silverchloride in a saturated solution of potassium chloride. Mass concentration of the antibiotic was calculated by the method of the additive mixture in a certified solution to be analyzed. Delete oxygen carried out by bubbling of nitrogen.

\section{Results and discussion}

On the model solutions studied by choice of operating conditions (background electrolyte, potential (Ee) and the electrolysis time ( $\mathrm{t}$ )) receiving antibiotics analytical signals. When determining drugs plays crucial $\mathrm{pH}$ because it affects the rate and mechanism of the electrode process. The dependence of the maximum potential of the cathode of the peaks of the investigated antibiotics $\mathrm{pH}$ is complex. The $\mathrm{pH}$ change resulted in a change of the peak shape, or to shift it. Offset potential towards more negative value indicates a loss recovery process antibiotic that may be related to the preceding reaction protolytic deprotonation of the protonated forms of antibiotics. May precede the deprotonation step an electron transfer from the electrode to the molecule depolarizer or occurs simultaneously with it. In this regard, we have conducted research on the effects of cation-anion composition of electrolytes and $\mathrm{pH}$. It was found that the best background for Tiltar electrolyte is $0.1 \mathrm{~mol} / \mathrm{dm}^{3} \mathrm{C}_{6} \mathrm{H}_{8} \mathrm{O}_{7} \cdot 2 \mathrm{HN}_{3}$ for gentamicin - background $0.1 \mathrm{M} \mathrm{NaC}_{4} \mathrm{H}_{4} \mathrm{O}_{6}\left(\mathrm{pH}_{5}-\right.$ 6 ), and for cephalexin - background $\mathrm{Na}_{3} \mathrm{C}_{6} \mathrm{H}_{5} \mathrm{O}_{7} 0.1 \mathrm{M}(\mathrm{pH} 4-5)$ where voltammograms recorded with a distinct analytical signal and good reproducibility.

The dependence of the peak current on the potential electrolysis and concentration on RPE antibiotics. Selected potentials are accumulating in which there is maximum analytical signals antibiotics. Antibiotics studied peak current depending on the concentration of the solution.

The obtained calibration relation is stored in the concentration range of tylosin tartrate (CTiltar) $(0.10-1.70) \mathrm{g} / \mathrm{dm}^{3}$, gentamicin $(0.1-10.0) \mathrm{g} / \mathrm{dm}^{3}$ and cephalexin $(0.1-2.0) \mathrm{g} / \mathrm{dm}^{3}$. At higher concentrations, there is a deviation from the linearity of the calibration curve, which, apparently, due to the saturation of the surface of the indicator electrode. Analytical signal tylosin tartrate first obtained under these conditions is shown voltammograms (Figure 1).

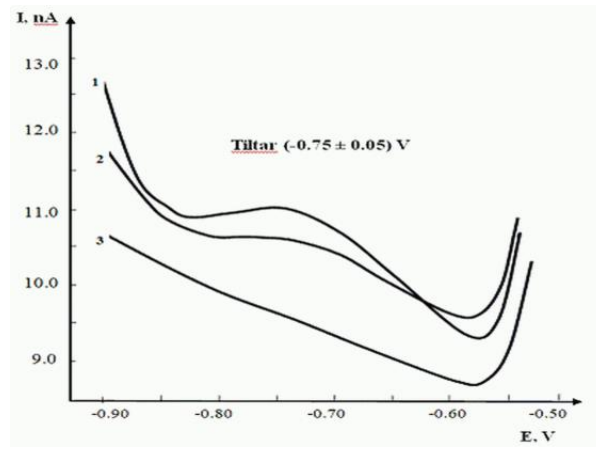

Fig. 1. Voltammograms Tiltar ( $\mathrm{t} \ni=30 \mathrm{~s}): 1-0.1 \mathrm{~mol} / \mathrm{dm}^{3} \mathrm{C}_{6} \mathrm{H}_{8} \mathrm{O}_{7} \cdot 2 \mathrm{HN}_{3}, \mathrm{pH} 6 ; 2-\mathrm{C}_{\text {Tiltar }}=0.2 \mathrm{~g} / \mathrm{dm}^{3}$;

$3-\mathrm{C}_{\text {Tiltar }}=0.4 \mathrm{~g} / \mathrm{dm}^{3}$

As can be seen (Figure 1) on the voltammogram observed a pronounced Tiltar signal at a potential maximum cathodic peak $\mathrm{E}=-0.75 \mathrm{~V}$. The introduction of certified additives mixture, proportional to the concentration entered an antibiotic increases the analytical signal that indicate the possibility of quantification.

Voltammograms CF and GS for the first time obtained under these conditions are shown in Figure 2.

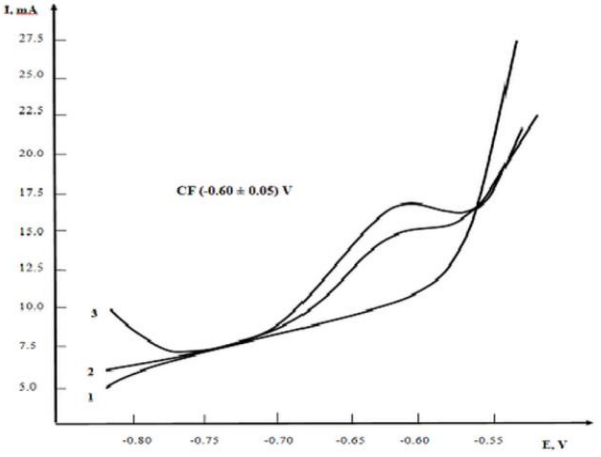


a)

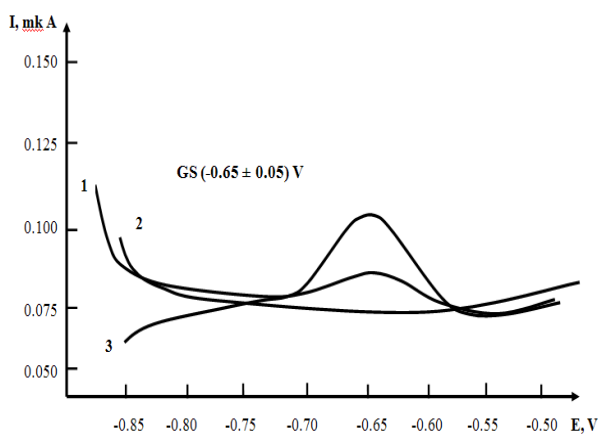

b)

Fig. 2. Voltammograms cephalexin (a) and gentamicin (b) on RPE: a) 1 - background solution - $0.1 \mathrm{M} \mathrm{Na}_{3} \mathrm{C}_{6} \mathrm{H}_{5} \mathrm{O}_{7}, \mathrm{pH}_{4}$-5; Eэ $=-0.35 \mathrm{~V}$, tэ $=30 \mathrm{~s} ; 2-\mathrm{C}_{\mathrm{CF}}=0.2 \mathrm{~g} / \mathrm{dm}^{3} ; 3-\mathrm{C}_{\mathrm{CF}}=0.4 \mathrm{~g} / \mathrm{dm}^{3} ;$ b) 1 - background solution $0.1 \mathrm{M} \mathrm{NaC}_{4} \mathrm{H}_{4} \mathrm{O}_{6} \cdot \mathrm{H}_{2} \mathrm{O}, \mathrm{pH} \mathrm{5-6}$, Еэ $=-0.3 \mathrm{~V}, \mathrm{t}$ э $=30 \mathrm{~s} ; 2-\mathrm{C}_{\mathrm{GS}}=2 \mathrm{~g} / \mathrm{dm}^{3} ; 3-\mathrm{C}_{\mathrm{CS}}=4 \mathrm{~g} / \mathrm{dm}^{3}$.

As can be seen from Figure 2 voltammograms there are well-defined signals $\mathrm{CF}$ at $\mathrm{E}=-0.60 \mathrm{~V}$, and in GS at $\mathrm{E}=-0.65 \mathrm{~V}$. The introduction of additive mixtures of certified analytical signals antibiotics increase proportionally to the introduced concentration, indicating that the possibility of quantification. An algorithm for the sample preparation of drugs, which is simple and reduces the sample to dissolve in water. In some cases, when the antibiotic is administered in a feed additive, to better carry out the deposition of the matrix requires the hydrolysis of $0.1 \mathrm{~mol} / \mathrm{dm}^{3} \mathrm{HCl}$, and zinc sulfate salting (to saturation).

Using the proposed algorithm, the analysis of real-world objects with the declared content of antibiotics. The results and the method of checking the correctness of «added-found» in the table.

Table. The results of VA-determination of antibiotics and validation method of «added-found» $(\mathrm{P}=0,95, \mathrm{n}=3)$

\begin{tabular}{|c|c|c|c|c|}
\hline \multirow[b]{2}{*}{ Object } & \multirow[b]{2}{*}{ Antibiotic } & \multicolumn{3}{|c|}{ Contents, g/g } \\
\hline & & $\begin{array}{c}\text { On packing } \\
\text { producer } \\
\text { (in test) }\end{array}$ & Introduce & Find \\
\hline \multirow[t]{2}{*}{$\begin{array}{c}\text { «Farmazin» } \\
\text { «HUVEPHAPMA», Bulgaria }\end{array}$} & \multirow[t]{2}{*}{ Tylosinum tartrat } & \multirow{2}{*}{0.50} & It isn't entered & $0.48 \pm 0.05$ \\
\hline & & & 0.40 & $0.93 \pm 0.15$ \\
\hline \multirow{2}{*}{$\begin{array}{c}\text { «Cephalex», } \\
\text { «SP Veterinaria, SA», Spain }\end{array}$} & \multirow{2}{*}{ Gentamycin } & \multirow{2}{*}{0.50} & It isn't entered & $0.51 \pm 0.05$ \\
\hline & & & 0.30 & $0.81 \pm 0.13$ \\
\hline \multirow{2}{*}{$\begin{array}{c}\text { «Gentamizin» } \\
\text { OOO «KPK d.d.», Slovenia }\end{array}$} & \multirow{2}{*}{ Gentamycini sulfas } & \multirow{2}{*}{0.10} & It isn't entered & $0.11 \pm 0,02$ \\
\hline & & & 0.10 & $0.20 \pm 0.03$ \\
\hline
\end{tabular}

As the table shows, the results are consistent with those declared by the manufacturer.

\section{CONCLUSION}

Based on the studies developed methodology for the voltammetric determination of antibiotics in aqueous solutions of drugs used in veterinary cephalexin content ranging from 0.1 to $2.0 \mathrm{~g} / \mathrm{dm}^{3}$, tylosine tartrate in the range from 0.1 to 1.7 $\mathrm{g} / \mathrm{dm}^{3}$ and gentamicin sulfate from 0.1 to $1.5 \mathrm{~g} / \mathrm{dm}^{3}$ ( $\mathrm{Sr}$ is not more than $25 \%$ ). The methods are simple to implement, do not require costly and can be used for detection of counterfeit products.

\section{References}

1. Biomedia of the Russian Federation. Popular scientific portal. [Electronic resource]//access Mode: URL: http://биомедиа.рф 
2. B. Peset Praktikum according to the technical analysis and control in a priozvodstvo of chemical and pharmaceutical preparations and antibiotics (1981).

3. GOST P 53912-2010 Foodstuff. An express method of definition of antibiotics

4. G. Hancu, H. Kelemen, A. Rusu, A. Gyéresi, J. Serb. Chem. Soc. 78; 9 (2013).

5. T. Voyeykova, J. Biotechnology. 2 (2008). 